\title{
Ciliary Neurotrophic Factor Enhances Neuronal Survival in Embryonic Rat Hippocampal Cultures
}

\author{
Nancy Y. Ip, Yanping Li, Ingrid van de Stadt, Nikos Panayotatos, Ralph F. Alderson, and Ronald M. Lindsay \\ Regeneron Pharmaceuticals, Inc., Tarrytown, New York 10591
}

\begin{abstract}
First described as a survival factor for chick ciliary ganglion neurons, ciliary neurotrophic factor (CNTF) has recently been shown to promote survival of chick embryo motor neurons. We now report neurotrophic effects of CNTF toward three populations of rat hippocampal neurons, the first demonstration of effects of CNTF upon rodent CNS neurons in culture. CNTF elicited an increase in the neurofilament content of hippocampal cultures prepared from embryonic day 18 (E18) rat brain. This was accompanied by increases of 2-, 28-, and 3-fold in the number of GABAergic, cholinergic, and calbindin-immunopositive cells, respectively. CNTF totally prevented the $67 \%$ loss of GABAergic neurons that occurred in control cultures over $8 \mathrm{~d}$. CNTF also increased high-affinity GABA uptake and glutamic acid decarboxylase activity. Effects of CNTF were in all cases dose dependent, with maximal stimulation at approximately $100 \mathrm{pg} / \mathrm{ml}$. When addition was delayed for $3 \mathrm{~d}$, CNTF failed to elicit increases either in the number of cholinergic neurons or in GABA uptake.
\end{abstract}

Until recently, NGF was the only fully characterized neurotrophic factor (Levi-Montalcini and Angeletti, 1968; Thoenen and Barde, 1980; Thoenen et al., 1987), although a number of other putative neurotrophic factors had been described and purified (Barde, 1988, 1989). Like NGF, these activities have been found to be important in supporting survival and differentiation of distinct neuronal populations in the developing nervous system (Lindsay, 1988; Purves, 1988; Barde, 1989). Ciliary neurotrophic factor (CNTF) is among the small number of neurotrophic factors that have now been fully characterized through purification, protein sequencing, and molecular cloning. CNTF, initially purified from extracts of chick eye (Barbin et al., 1984) and subsequently from adult rat sciatic nerve (Manthorpe et al., 1986a; Lin et al., 1990), was first described as a neurotrophic activity that promoted the survival of parasympathetic neurons of the developing chick ciliary ganglion (Adler et al., 1979; Manthorpe and Varon, 1985). Both the molecular characteristics and neuronal specificities of CNTF distinguish it from any of the neurotrophin family of neurotrophic factors-NGF, brainderived neurotrophic factor (BDNF; Barde et al., 1982; Leibrock

\footnotetext{
Received Feb. 22, 1991; revised Apr. 30, 1991; accepted May 2, 1991.

We thank Drs. John S. Rudge and Stephen P. Squinto for their comments on the manuscript, Drs. Michael Sendtner and Hans Thoenen for providing us with the original recombinant rat CNTF plasmid, Dr. John Wood (Sandoz Institute, London) for the generous gift of RT97 antibody, and Dr. Leonard S. Schleifer for providing a stimulating environment at Regeneron.

Correspondence should be addressed to Dr. Nancy Y. Ip, Regeneron Pharmaceuticals, Inc., 777 Old Saw Mill River Road, Tarrytown, NY 10591.

Copyright (C) 1991 Society for Neuroscience $0270-6474 / 91 / 113124-11 \$ 05.00 / 0$
}

et al., 1989), and neurotrophin-3 (NT-3; Hohn et al., 1990; Maisonpierre et al., 1990a).

The initial biological activities described for CNTF were limited to the PNS, where there is evidence for trophic actions of CNTF on parasympathetic, sympathetic, and some sensory neurons (Manthorpe and Varon, 1985). To date, studies of effects of CNTF within the CNS have been limited. However, there have been several recent reports indicating effects of CNTF on the survival of developing motor neurons (Arakawa et al., 1990; Wong et al., 1990), including an in vivo study that showed that locally applicd CNTF prevented lesion-induced degeneration of motor neurons in the facial nerve nucleus following transection of the facial nerve in newborn rats (Sendtner et al., 1990). Another in vivo study has also suggested that CNTF may support the survival of preganglionic sympathetic spinal cord neurons (Blottner et al., 1989). As with most neurotrophic factors, except for NGF, progress in elucidating the neuronal specificities and other biological actions of CNTF has been greatly impeded by the limited availability of the protein, this being a consequence of the low abundance of neurotrophic factors. The recent cloning of rat, rabbit, and human CNTF (Lin et al., 1989; Stöckli et al., 1989; Masiakowski et al., 1991) has led to high-level expression and purification of recombinant $\mathrm{CNTF}$, which will now facilitate studies of possible neurotrophic activities of CNTF toward CNS neurons.

Recent studies on the distribution of CNTF by Northern analysis have shown CNTF mRNA to be present in several regions of the brain (N. Y. Ip, P. Masiakowski, and G. D. Yancopoulos, unpublished observations). This raises the possibility that, in addition to its recently described effects on motor neurons, CNTF may act as a neurotrophic factor for distinct populations of CNS neurons. As part of an attempt to define the neuronal specificity(ies) of CNTF toward CNS neurons, we examined effects of CNTF on the survival and differentiation of embryonic rat hippocampal neurons in culture.

\section{Materials and Methods}

Hippocampal cell cultures. Hippocampi were dissected from embryonic day 18-19 (E18-19) embryos of Sprague-Dawley rats and collected in F10 medium (GIBCO). The tissues were minced, rinsed twice with F10 medium, and trypsinized with $0.25 \%$ trypsin (GIBCO) for $20 \mathrm{~min}$ at $37^{\circ} \mathrm{C}$. Trypsin was inactivated by the addition of a serum-containing medium composed of minimal essential medium (MEM) supplemented with fetal calf serum (FCS; $10 \%)$, glutamine $(2 \mathrm{~mm})$, penicillin $(25 \mathrm{U} /$ $\mathrm{ml})$, and streptomycin $(25 \mu \mathrm{g} / \mathrm{ml})$. Dissociated cells obtained by gentle trituration were collected and centrifuged at low speed $(500 \mathrm{rpm})$ for $30 \mathrm{sec}$. The centrifugation was repeated twice, and the cell pellets were resuspended in serum-containing medium. The cells were then plated onto $6 \mathrm{~mm}$ microtiter wells that were coated with polyornithine $(10 \mu \mathrm{g}$ $\mathrm{ml})$ and laminin $(10 \mu \mathrm{g} / \mathrm{ml})$. Five to six hours following the plating of 
cells, medium was changed to a serum-free medium containing N3 supplements (Romijn et al., 1982) and penicillin-streptomycin (25 $\mathrm{U} / \mathrm{ml}$ and $25 \mathrm{\mu g} / \mathrm{ml}$, respectively), at which time CNTF was added. Medium was changed every $3-4 \mathrm{~d}$, with readdition of the factor. Except where noted, the plating density used for the experiments described in the present study was 71,000 cells $/ \mathrm{cm}^{2}$.

To obtain neuron-enriched cultures, cytosine arabinoside $(1 \mu \mathbf{M})$ or fluorodeoxyuridine (FUdr) $(15 \mu \mathrm{g} / \mathrm{ml})$ and uridine $(35 \mu \mathrm{g} / \mathrm{ml})$ were added for a period of $24 \mathrm{hr}$. Under such conditions, the hippocampal cultures contain approximately $9 \%$ glial cells following $8 \mathrm{~d}$ in culture, as assessed by glial fibrillary acidic protein (GFAP) immunohistochemistry.

Assay for glutamic acid decarboxylase (GAD) enzyme activity. GAD enzyme activity was determined according to the method of Kimura and Kuriyama (1975) by measuring the release of ${ }^{14} \mathrm{CO}_{2}$ from $\mathrm{L}-\left[1-{ }^{14} \mathrm{C}\right]$ glutamic acid. Cells on $35-\mathrm{mm}$ dishes were lysed with $30 \mu \mathrm{l}$ of a solution containing $50 \mathrm{mM} \mathrm{KH}_{2} \mathrm{PO}_{4}(\mathrm{pH} 7.2)$ and $0.25 \%$ Triton $\mathrm{X}-100$, scraped, and collected. Five microliters of the cell lysate was assayed for GAD enzyme activity. In a typical assay, the reaction mixture contained 0.57 mM L- $\left[1-{ }^{14} \mathrm{C}\right]$-glutamic acid [New England Nuclear (NEN), NEC-715; $52.6 \mathrm{mCi} / \mathrm{mmol}$, glutamic acid (3 $\mathrm{mm})$, pyridoxal phosphate $(0.2 \mathrm{~mm})$, and 2-aminoethylisothiouronium bromide (AET; $1 \mathrm{~mm}$ ), in a $\mathrm{KH}_{2} \mathrm{PO}_{4}$ buffer ( $50 \mathrm{~mm}, \mathrm{pH} 7.2$ ). Under these reaction conditions, the enzyme reaction was found to be linear for up to $2.5 \mathrm{hr}$. An incubation period of $2 \mathrm{hr}$ at $37^{\circ} \mathrm{C}$ was routincly used and the reaction was terminated by injecting $25 \mu \mathrm{l}$ of $8 \mathrm{~N} \mathrm{H}_{2} \mathrm{SO}_{4}$ into the reaction mixture. The incubation was then continued for another $60 \mathrm{~min} .{ }^{14} \mathrm{C}-\mathrm{CO}_{2}$ released was trapped in methyl benzethonium hydroxide and was counted.

Measurement of neurofilament protein. Neurofilament protein was quantitated according to the method by Doherty et al. (1984). Following fixation with $4 \%(\mathrm{v} / \mathrm{v})$ paraformaldehyde for at least $4 \mathrm{hr}$ at $4^{\circ} \mathrm{C}$, the cultures were permeabilized with $0.1 \%(\mathrm{v} / \mathrm{v})$ Triton $\mathrm{X}-100$ in PBS for $15 \mathrm{~min}$ and blocked with $10 \%$ heat-inactivated FCS in PBS for $1 \mathrm{hr}$. The cultures were then incubated with mouse anti-neurofilament immunoglobulin (RT97, 1:1000) for $1 \mathrm{hr}$ at room temperature, washed twice with PBS containing $10 \% \mathrm{FCS}$, and incubated with the secondary antibody (horseradish peroxidase-conjugated sheep anti-mouse at 1:500 dilution) for $1 \mathrm{hr}$. Following sequential washing with PBS and water, the cultures were incubated with $0.2 \%(\mathrm{w} / \mathrm{v}) O$-phenylenediamine and $0.02 \%(\mathrm{v} / \mathrm{v}) \mathrm{H}_{2} \mathrm{O}_{2}$ in citrate buffer $(50 \mathrm{~mm})$ for $30 \mathrm{~min}$. The reaction was stopped by adding an equal volume of $4.5 \mathrm{M} \mathrm{H}_{2} \mathrm{SO}_{4}$. Product formation was quantitated by reading the optical density (O.D.) of an aliquot of the reaction product at $492 \mathrm{~nm}$ using the Flow Titretek multiscan apparatus.

Measurement of high-affinity uptake for $G A B A$. High-aftinity GABA uptake was measured using a modified procedure of Tomozawa and Appel (1986). Cells were washed in the GABA uptake buffer containing $140 \mathrm{~mm} \mathrm{NaCl}, 2.5 \mathrm{~mm} \mathrm{KCl}, 1 \mathrm{~mm} \mathrm{KH} \mathrm{PO}_{4}, 1 \mathrm{~mm} \mathrm{Na} \mathrm{HPO}_{4}, 6 \mathrm{mg} / \mathrm{ml}$ glucose, $1 \mathrm{mM} \mathrm{MgCl}_{2}, 1 \mathrm{mM} \mathrm{CaCl}_{2}$, and $0.1 \% \mathrm{BSA}$. Following washing, cells were incubated with the GABA uptake buffer for $5 \mathrm{~min}$ at $37^{\circ} \mathrm{C}$. ${ }^{3} \mathrm{H}-\mathrm{GABA}$ (NEN, NET-191X;111.4 Ci/mmol) was then added at a final concentration of $12 \mathrm{nM}$, and incubation was carried out at $37^{\circ} \mathrm{C}$ for 10 min. Cells were kept on ice and washed three times with the uptake buffer. Cells were then incubated with $0.14 N \mathrm{NaOH}$ for $2 \mathrm{hr}$ at room temperature, and ${ }^{3} \mathrm{H}-\mathrm{GABA}$ in the extract was counted. ${ }^{3} \mathrm{H}-\mathrm{GABA}$ uptake was found to be linear for up to at least $30 \mathrm{~min}$. Uptake of GABA into non-neuronal cells was inhibited by the addition of $2 \mathrm{~mm} \beta$-alanine, whereas uptake specific for neurons is verified by inhibition with nipecotic acid at $1 \mathrm{~mm}$. Nipecotic acid was found to inhibit total GABA uptake in hippocampal cultures by $88 \%$. Specific neuronal GABA uptake was determined as GABA uptake that was blocked in the presence of $1 \mathrm{mM}$ nipecotic acid. It is noteworthy that CNTF treatment only affected the GABA uptake that was blocked by nipecotic acid, and not the level of nipecotic acid-independent GABA uptake.

Immunohistochemical staining for $G A D$ or $G A B A$. Cells were fixed with $4 \%$ paraformaldehyde for $30 \mathrm{~min}$ at room temperature and washed with PBS. For GAD staining, cells were permeabilized by sequential rinsing with $50 \%, 70 \%$, and $50 \%$ ethanol. The cultures were blocked with PBS containing 5\% normal rabbit serum for $1 \mathrm{hr}$ and incubated with sheep anti-GAD antibody 1440 (1:6000) overnight at $4^{\circ} \mathrm{C}$. Following three rinses with PBS, cells were then incubated with biotinylated rabbit anti-sheep antibody at a 1:400 dilution for at least $90 \mathrm{~min}$ at room temperature. For GABA staining, cells were permeabilized with Triton X-100 (0.25\%) in Tris- $\mathrm{HCl}(0.1 \mathrm{M}, \mathrm{pH} 7.3)$ and blocked with $10 \%$ normal goat serum (NGS) for $90 \mathrm{~min}$, prior to incubation with rabbit anti-GABA antibody (1:5000) overnight at $4^{\circ} \mathrm{C}$. Following three rinses with $\mathrm{PBS}$, cells were then incubated with the biotinylated goat anti-rabbit antibody at a 1:200 dilution for at least $90 \mathrm{~min}$ at room temperature. GAD- or GABA-immunoreactive cells were visualized using the Vectastain ABC kit (Vector Labs).

Immunohistochemical staining for neuron-specific enolase, calbindin, or ChAT. Cells were rinsed twice with PBS and fixed with $4 \%$ paraformaldehyde for $30 \mathrm{~min}$ at room temperature. For neuron-specific enolase (NSE) staining, cells were blocked with $10 \%$ normal goat serum in PBS containing $0.1 \%$ Triton $\mathrm{X}-100$. The cells were then incubated with the primary antibody (rabbit anti-NSE, 1:5000) overnight at $4{ }^{\circ} \mathrm{C}$ prior to incubation with the secondary antibody (goat anti-rabbit, 1:200 dilution) for at least $90 \mathrm{~min}$ at room temperature. For calbindin staining, cells were permeabilized, washed with $1 \%$ normal horse serum (NHS), and blocked with 5\% NHS in PBS for $1 \mathrm{hr}$ at room tcmpcraturc. Cclls were then incubated with a mouse antibody raised against the $28-\mathrm{kDa}$ species of calbindin (1:1000) in $1 \%$ NHS overnight at $4{ }^{\circ} \mathrm{C}$, prior to incubation with the secondary antibody (biotinylated horse anti-mouse, 1:400) for $90 \mathrm{~min}$ at room temperature. For ChAT staining, cells were permeabilized with Triton $\mathrm{X}-100(0.25 \%)$ in Tris- $\mathrm{HCl}(0.1 \mathrm{M}, \mathrm{pH} 7.3)$ and blocked with $10 \%$ normal rabbit serum for $60 \mathrm{~min}$ prior to incubation with a rat anti-ChAT monoclonal antibody $(1: 200)$ overnight at $4^{\circ} \mathrm{C}$. Incubation with the secondary antibody (rabbit anti-rat, 1:1500) was for $60 \mathrm{~min}$ at room temperature. Immunoreactive cells for NSE or calbindin were visualized by using the Vectastain ABC kit.

Histochemical staining for acetylcholinesterase. Histochemical staining for acetylcholinesterase was performed according to the procedures of Geneser-Jensen and Blackstadt (1971). Cells were washed three times with PBS and fixed with $4 \%$ paraformaldehyde at room temperature for $30 \mathrm{~min}$. The fixed cells were then incubated with a reaction mixture containing $50 \mathrm{~mm}$ acetate buffer ( $\mathrm{pH} 5.0$ ), $4 \mathrm{~mm}$ acetylthiocholine iodide, $2 \mathrm{~mm}$ copper sulfate, $10 \mathrm{~mm}$ glycine, and $10 \mu \mathrm{g} / \mathrm{ml}$ gelatin. Nonspecific cholinesterases were inhibited by including $0.2 \mathrm{~mm}$ ethopropazine in the incubation medium. Specificity of the cholinesterase staining was verified by the addition of neostigmine at $5 \mu \mathrm{M}$. In the presence of neostigmine, no AChE-positive cells were observed. At the end of a 7 $\mathrm{d}$ incubation, gelatin was dissolved by brief incubation at $37^{\circ} \mathrm{C}$. The cells were washed with water, treated for $1 \mathrm{~min}$ with $1.25 \% \mathrm{Na}_{2} \mathrm{~S}$, and washed again with water. They were then treated for $1 \mathrm{~min}$ with $1 \%$ $\mathrm{AgNO}_{3}$ and washed with water and PBS.

Purification of CNTF. The purification of recombinant rat CNTF used for the present study was carried out as described previously (Masiakowski et al., 1991).

\section{Results}

\section{CNTF sustains survival of hippocampal neurons}

Hippocampal neurons from E18 rat embryos, when plated on polyornithine-laminin coated tissue culture dishes, exhibited rapid neurite outgrowth by $7 \mathrm{hr}$ in culture (Fig. $1 \mathrm{~A}$ ). Continued neurite extension was visually notable for the first few days in culture. During this period, there were few non-neuronal cells present (Fig. $1 B-D$ ). Without treatment to reduce non-neuronal cell proliferation, the neuronal population represented more than $60 \%$ of the total cell number by the end of $8 \mathrm{~d}$ in culture (Fig. $1 E)$. There were no apparent differences in neuronal morphologies observed between control and CNTF-treated cultures during the first $4 \mathrm{~d}$ in vitro. Between 4 and $8 \mathrm{~d}$, however, there was a large decrease in the number of neurons in control cultures. In initial experiments, immunoreactivity for NSE was used as a marker to examine the effect of CNTF on neuronal number following $8 \mathrm{~d}$ of treatment (Fig. $1 F, G$ ). By this criterion, the number of neurons in CNTF-treated cultures was approximately twofold higher than in untreated controls. This effect of CNTF on the number of NSE-positive cells was essentially the same at the standard and lower plating densities used (Fig. $1 A-E$ and $F, G$, respectively).

\section{Neurofilament protein content is increased by CNTF}

To examine any broad effects of CNTF on neurite outgrowth in hippocampal cultures, levels of neurofilament protein were 

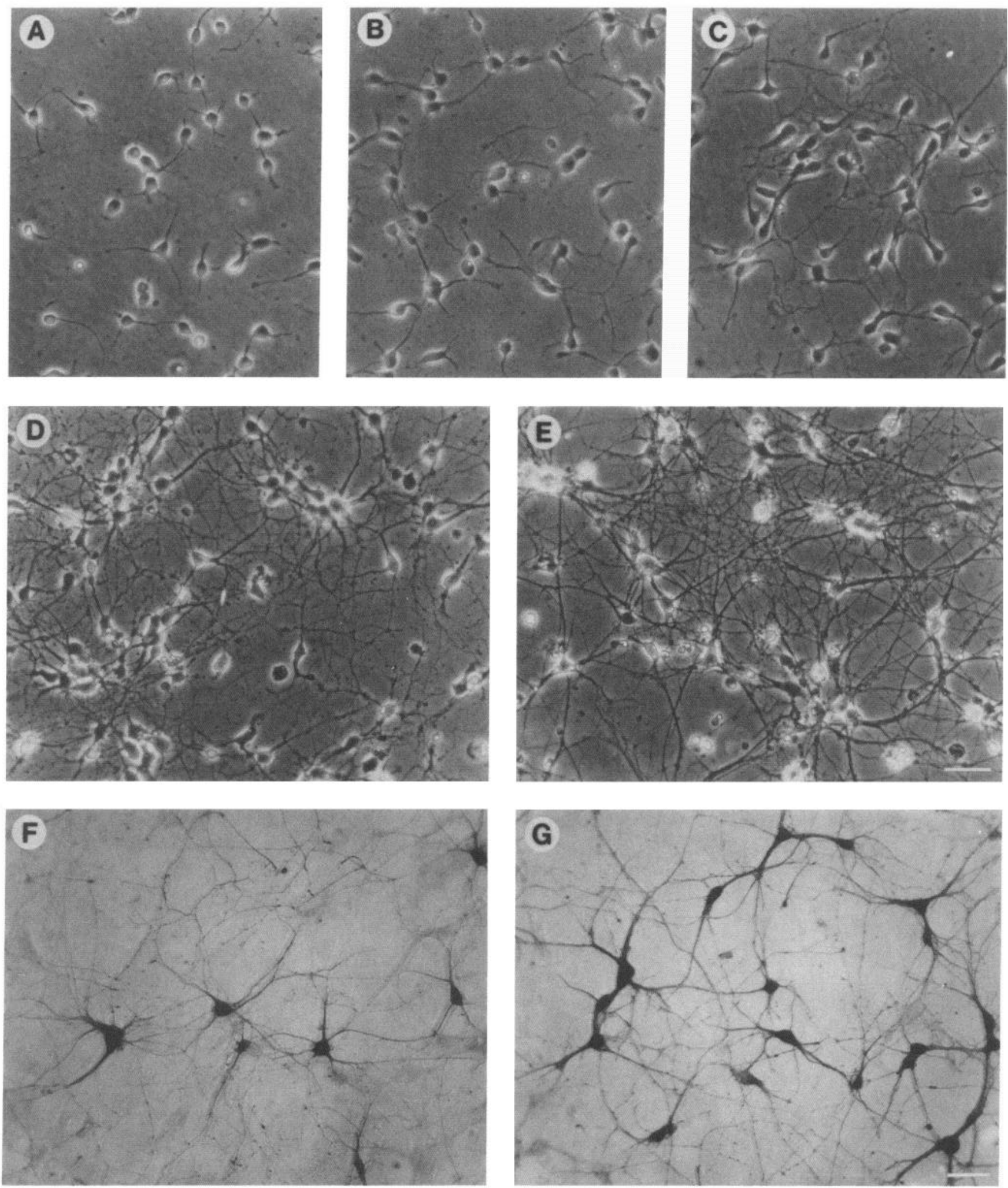

Figure 1. Hippocampal cell cultures. Phase-contrast photomicrographs of hippocampal cultures following $7 \mathrm{hr}$ and $1,2,4$, and $8 \mathrm{~d}$ in culture are shown in $A-E$, respectively. $F$ and $G$ show neurons identified with NSE following $8 \mathrm{~d}$ in culture in the absence or presence of $10 \mathrm{ng} / \mathrm{ml} \mathrm{CNTF}$, respectively. Cells were plated at a density of $71,000 / \mathrm{cm}^{2}$ for $A-E$, and $25,000 / \mathrm{cm}^{2}$ for $F$ and $G$. Scale bars, $50 \mu \mathrm{m}$.

measured using an ELISA, as previously described (Doherty et al., 1984, 1987). The RT97 monoclonal antibody that was used recognized predominantly the $200 \mathrm{kDa}$ form of the neurofilament protein triplet (Robinson and Anderton, 1988). CNTF (10 $\mathrm{ng} / \mathrm{ml}$ ) produced a $50 \%$ increase in neurofilament protein levels after $6 \mathrm{~d}$, which was further increased to $480 \%$ of control levels by day 8 in culture. The large difference between neurofilament levels in control and CNTF-treated cultures after $8 \mathrm{~d}$ partly 
Table 1. Comparison of the number of ChAT- and AChE-positive neurons in control and CNTF-treated cultures

\begin{tabular}{lcc} 
& ChAT-positive cells & AChE-positive cells \\
\hline Control & $13 \pm 2$ & $12 \pm 3$ \\
CNTF-treated & $269+13$ & $214 \pm 9$
\end{tabular}

Hippocampal cultures were maintained in the presence or absence of CNTF (10 $\mathrm{ng} / \mathrm{ml}$ ) for $8 \mathrm{~d}$, and the numbers of ChAT- or AChE-positive cells were determined. Results are the mean \pm SEM $(n=5-10)$.

reflected an increase in neurofilament protein in treated cultures and partly reflected the degencration and loss of ncurons in untreated cultures. When compared to untreated controls following $8 \mathrm{~d}$ in culture, neurofilament protein levels increased in a dose-dependent manner with CNTF treatment (Fig. 2). The response to CNTF was maximal at $0.1 \mathrm{ng} / \mathrm{ml}$, representing a sixfold increase compared to untreated controls, while the $\mathrm{EC}_{50}$ was calculated to be $0.02 \mathrm{ng} / \mathrm{ml}(0.9 \mathrm{pm})$. Higher concentrations of up to $10 \mathrm{ng} / \mathrm{ml}$ did not further increase the response.

\section{CNTF increases the number of GABAergic, cholinergic, and calbindin-immunopositive cells}

The large increase in neurofilament protein in response to CNTF treatment suggested that a relatively large percentage of the neurons were responding to the factor. The responding neuronal population(s) was further delineated on the basis of immunoand histochemical staining (Fig. 3). Based on GABA or GAD immunoreactivity, approximately $20 \%$ of the ncurons in control cultures were GABAergic, following $8 \mathrm{~d}$ in culture. In the presence of $C N T F$, there was an approximately twofold increase in the number of GABAergic neurons (Figs. $3 A, B ; 4 A$ ). The effect of CNTF on GABAergic cells was further confirmed by GAD immunohistochemical staining, where a similar increase of twofold was observed with CNTF treatment (data not shown).

Putative effects of CNTF on two other cell populations of hippocampal neurons, cholinergic and calbindin-immunopositive cells, were examined (Fig. $3 C, E$ ). Based on previous studies that have reported the presence of a small population of intrinsic cholinergic neurons in the hippocampus (Storm-Mathisen, 1970; Fonnum et al., 1979; Frotscher et al., 1986), we examined the number of AChE-positive cells in our cultures. In untreated cultures following $8 \mathrm{~d}$ in vitro, AChE-positive cells made up a very small percentage $(0.2 \%)$ of the total number of neurons. In agreement with previous obscrvations (Frotscher et al., 1986), the AChE-positive cells were relatively small and were weakly stained (Fig. 3 C). Treatment of cultures with CNTF produced a large increase in the number of AChE-positive cells compared to untreated controls, approximately 28 -fold, when examined after $8 \mathrm{~d}$ (Figs. 3D, 4B). AChE staining by itself is not sufficient to define a cholinergic phenotype. However, as we observed a similar fold increase in the number of ChAT-immunopositive cells following CNTF treatment (Table 1), we feel that the majority of the AChE-positive cells do represent cholinergic neurons. Interestingly, in contrast to what has been observed in cultures of other CNS cholinergic neurons (Hartikka and Hefti, 1988; Alderson et al., 1990), NGF produced no significant increase in the number of AChE-positive cells when tested at concentrations of $10-50 \mathrm{ng} / \mathrm{ml}$ (data not shown). In untreated cultures, a small number of calbindin-immunopositive cells werc found (Fig. $3 E$ ), which represented approximately $4 \%$ of the neuronal population following $8 \mathrm{~d}$ in culture. Double-

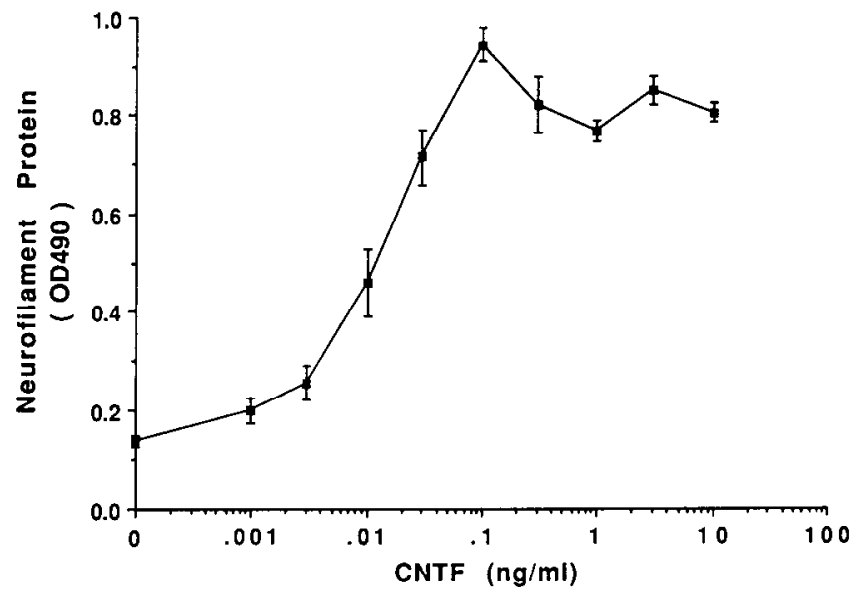

Figure 2. Dose-response curve of the CNTF-induced increase in neurofilament protein. Hippocampal neurons were cultured in the presence or absence of various concentrations of CNTF $(0.001-10 \mathrm{ng} / \mathrm{ml})$ for 8 d. At the end of the culture period, neurofilament protein levels were measured by ELISA as described in Materials and Methods. The results represent the mean $\pm \operatorname{SEM}(n=15)$.

labeling experiments showed that calbindin- and GABA-immunopositive cells represent distinct cell populations (data not shown). In the presence of CNTF, the number of calbindinimmunopositive cells was increased by threefold (Figs. $3 F, 4 B$ ). Taken together, these data suggest that CNTF can enhance the survival and/or expression of phenotypic markers of several subpopulations of hippocampal neurons in culture.

\section{CNTF rescues virtually all GABAergic neurons}

A detailed time course of the loss of GABA-immunopositive cells in control or CNTF-treated cultures was examined. As shown in Figure $5 A$, there was a gradual decline in the number of GABA-immunopositive cells in the control cultures between 1 and $8 \mathrm{~d}$. By day 8 , the number of GABA-immunopositive cells in control cultures was only $33 \%$ of that found in similar cultures on day 1. In contrast, in CNTF-treated cultures, the number of GABA-immunopositive neurons on days 4,6 , and 8 remained essentially constant, similar to that determined on day 1 . Thus, the data suggest that CNTF addition sustained survival of virtually all GABAergic neurons during the culture period. Similar studies were carried out using the general neuronal marker NSE (Fig. 5B). In control cultures, there was a gradual decline in the number of NSE-immunopositive cells after day 1 , with the number of neurons on day 8 falling to approximately $10 \%$ of that found on day 1 . In the presence of CNTF $(10 \mathrm{ng} / \mathrm{ml})$, the total number of NSE-immunopositive cells on day 8 was about 2.8 -fold higher than that seen in control cultures.

\section{GABA uptake and GAD activity are increased by CNTF}

In addition to studying effects on neuronal survival, the effect of CNTF on GABAergic phenotype expression was investigated by measuring changes in the level of high-affinity uptake of GABA and the levels of GAD activity in control and CNTFtreated cultures. CNTF treatment produced a $50 \%$ increase in GABA uptake by $5 \mathrm{~d}$ in culture, while a maximal increase of approximately fourfold, compared to controls, was observed after $8 \mathrm{~d}$ of CNTF treatment (Fig. 6). Longer culture periods of up to $11 \mathrm{~d}$ did not produce a greater effect of CNTF (see Fig. 

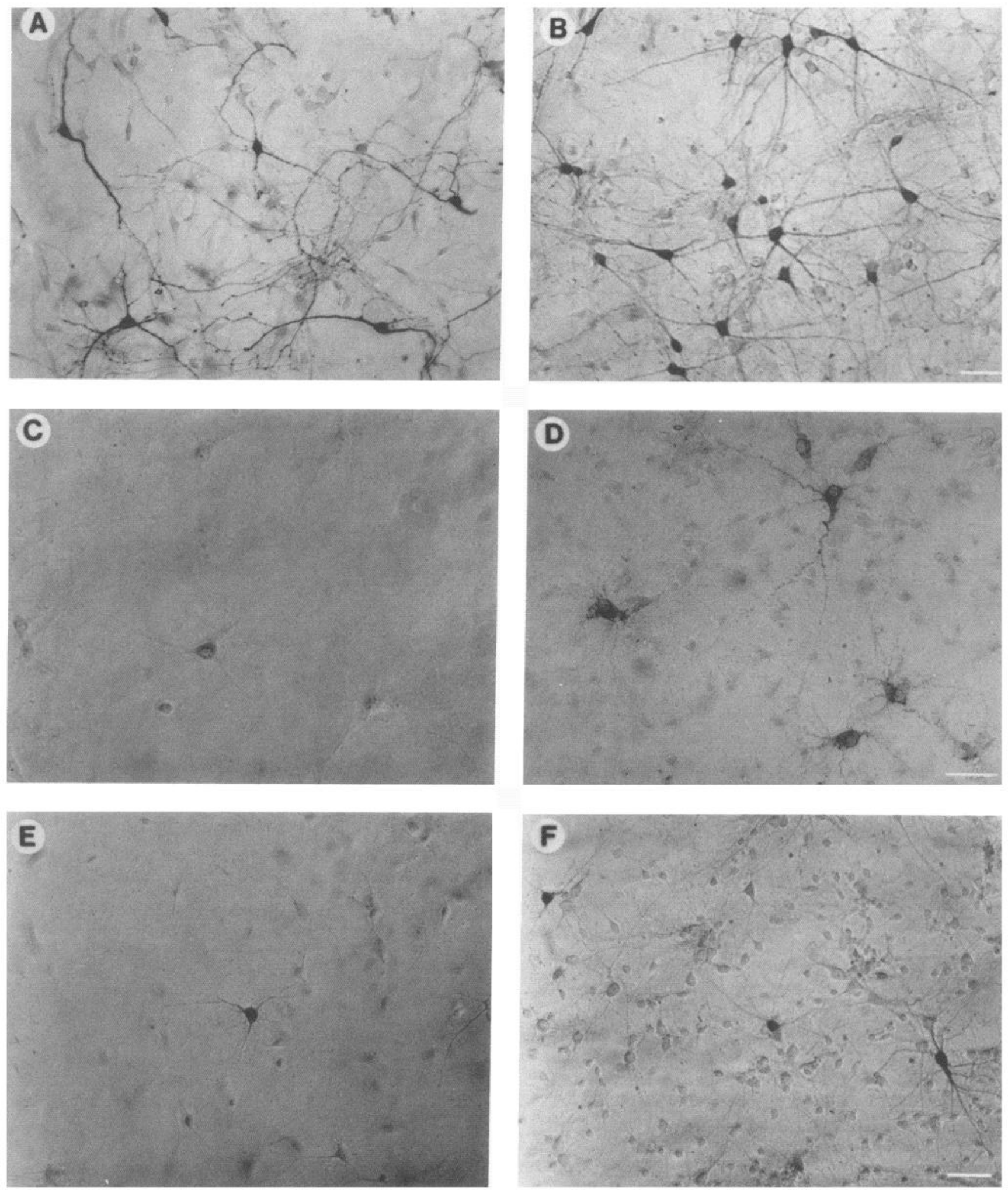

Figure 3. Immunocytochemical and histochemical detection of neuronal subpopulations of hippocampal cultures. Cell-type-specific markers were used to identify distinct subpopulations of hippocampal cells; GABA-immunopositive neurons ( $A$ and $B)$, AChE histochemically stained neurons $(C$ and $D)$, and calbindin-immunopositive neurons $(E$ and $F) . A, C$, and $E$ represent $8 \mathrm{~d}$ control cultures, while $B, D$, and $F$ represent CNTFtreated $(10 \mathrm{ng} / \mathrm{ml})$ cultures. Scale bars, $50 \mu \mathrm{m}$. 
A

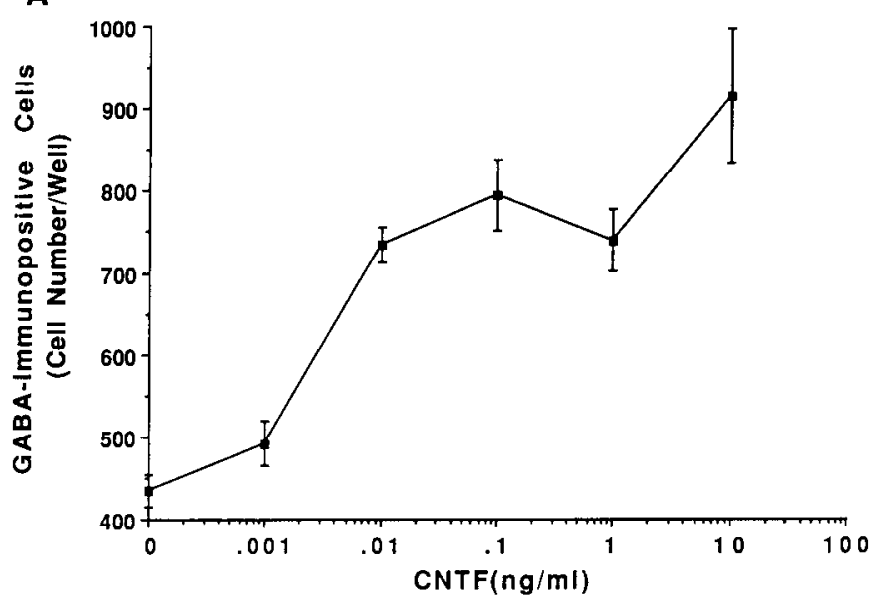

B

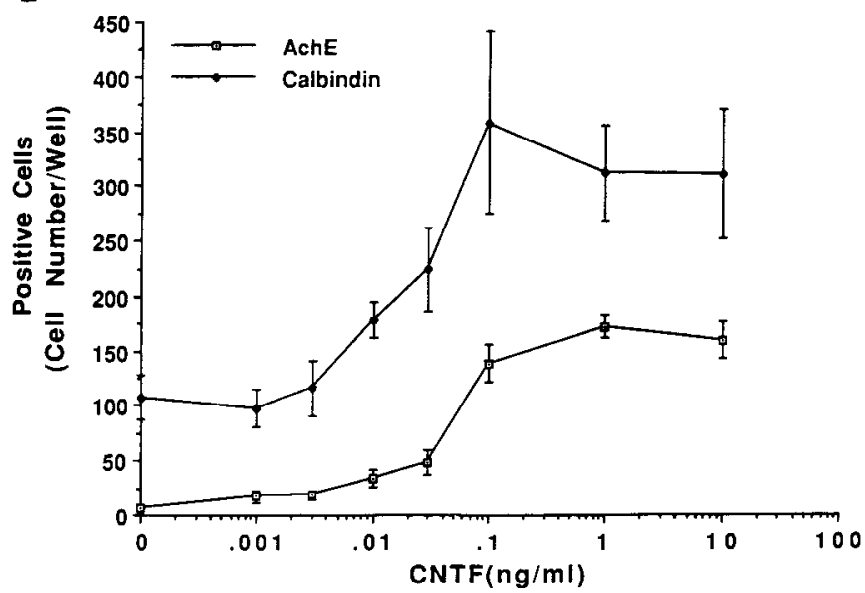

Figure 4. Dose-response effect of CNTF on the number of GABA$(A)$, AChE-, and calbindin-immunopositive $(B)$ neurons. Hippocampal neurons were grown in culture for $8 \mathrm{~d}$ in the presence or absence of various concentrations of CNTF $(0.001-10 \mathrm{ng} / \mathrm{ml})$. Immunocytochemical staining for GABA and calbindin, and histochemical staining of $\mathrm{AChE}$, were performed as described in Materials and Methods. The results represent the mean $\pm \operatorname{SEM}(n=5-15)$.

$8 B$ ). Treatment of cultures with $50 \mathrm{ng} / \mathrm{ml} \mathrm{NGF}$ did not result in any increase in high-affinity GABA uptake (data not shown). The response of the high-affinity GABA uptake to increasing concentrations of CNTF is shown in Figure $7 A$. A maximal increase of threefold in specific neuronal GABA uptake was obscrved with $0.1 \mathrm{ng} / \mathrm{ml}$ of CNTF. The response was saturable and was maximally stimulated even at a 100-fold higher concentration of CNTF. GAD activity was also observed to be increased following CNTF treatment and was maximally increased by 3.8 -fold following treatment with $0.1 \mathrm{ng} / \mathrm{ml} \mathrm{CNTF}$ (Fig. 7B).

\section{Is the effect of CNTF mediated by non-neuronal cells?}

Cultures of astroglial cells have been shown both to express and to release into culture medium a number of neurotrophic activities, including NGF, as reviewed in Manthorpe et al. (1986b). Given that our cultures contained a significant percentage of astroglial cells immunopositive for GFAP, we were interested to determine whether or not our observed effect of CNTF on hippocampal neurons might be indirectly mediated through action of CNTF on glial cells, as opposed to a direct action of
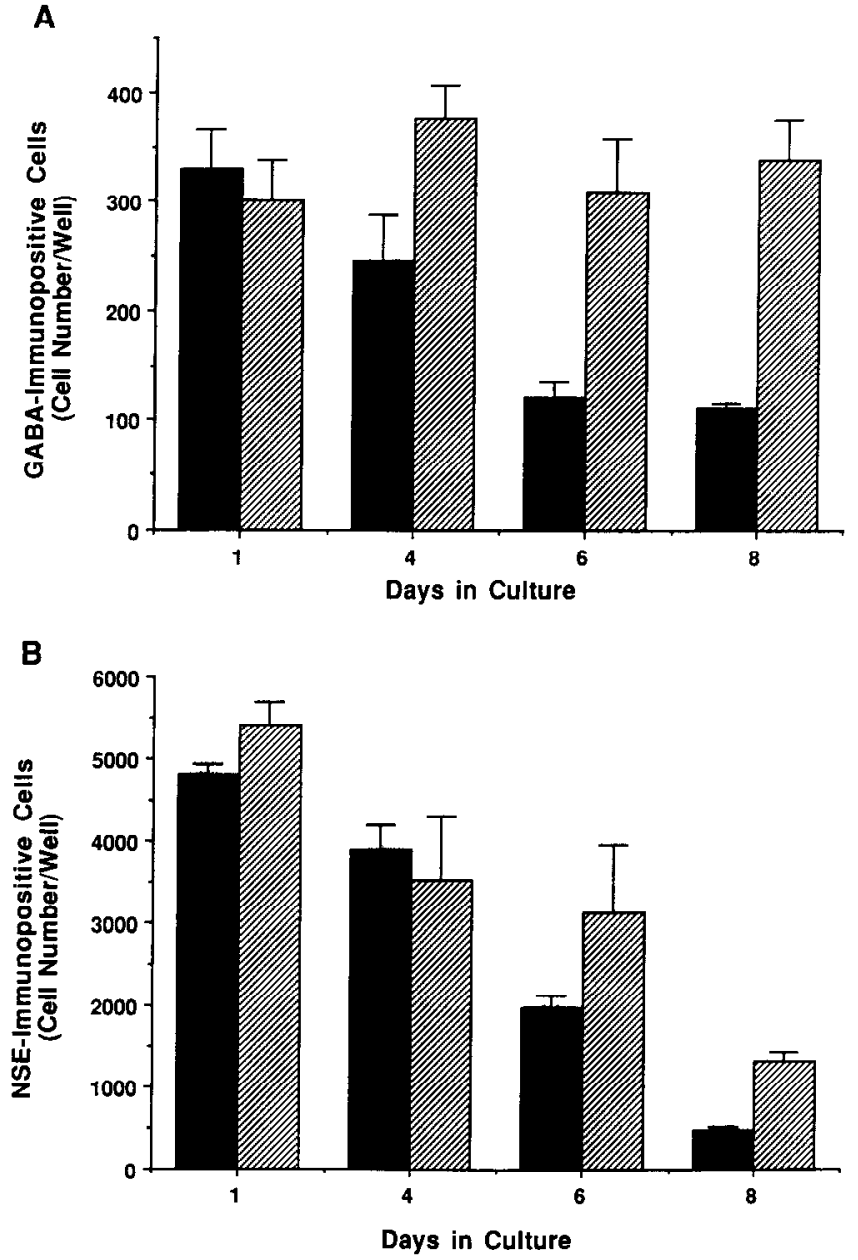

Figure 5. Time course of the number of GABA- $(A)$ or NSE-immunopositive $(B)$ neurons in CNTF-treated cultures. Hippocampal neurons were cultured and maintained in the presence or absence of CNTF (10 $\mathrm{ng} / \mathrm{ml}$ ) for various periods (1-8 d) prior to immunocytochemical detection of GABA- or NSE-positive neurons. The plating density was $17,500 \mathrm{cells} / \mathrm{cm}^{2}$. The results represent the mean $\pm \operatorname{SEM}(n=5)$. Solid bar, control cultures; hatched bar, CNTF-treated cultures.

CNTF on neurons. To address this question, we have performed experiments in which the effects of CNTF on high-affinity GABA uptake were compared in standard cultures and in cultures depleted of non-neuronal cells by the addition of the mitotic inhibitors cytosine arabinoside (AraC) or FUdr. Visual inspection

Table 2. CNTF-induced increase in high-affinity specific neuronal GABA uptake in the presence or absence of mitotic inhibitors

Percentage of untreated control

Control 100

CNTF

$\mathrm{CNTF} \pm \operatorname{AraC}(0.3 \mu \mathrm{M})$

$\mathrm{CNTF} \pm \operatorname{AraC}(1 \mu \mathrm{M})$

CNTF \pm FUdr $(15 \mu \mathrm{g} / \mathrm{ml})$

$309 \pm 20$

$255 \pm 5$

$316 \pm 55$

$421 \pm 17$

Hippocampal cultures were maintaincd in the presence or absence of CNTF (1 $\mathrm{ng} / \mathrm{ml})$ for $8 \mathrm{~d}$. AraC $(0.3$ or $1 \mu \mathrm{M})$ or FUdr $(15 \mu \mathrm{g} / \mathrm{ml})$ and uridine $(35 \mu \mathrm{g} / \mathrm{ml})$ were added to the hippocampal cultures for $24 \mathrm{hr}$ to reduce the number of glia. High-affinity specific neuronal GABA uptake was measured on day 8 in culture. The results represent the level of GABA uptake of treated cultures expressed as a percentage of untreated control cultures $\pm \operatorname{SEM}(n=6)$. 


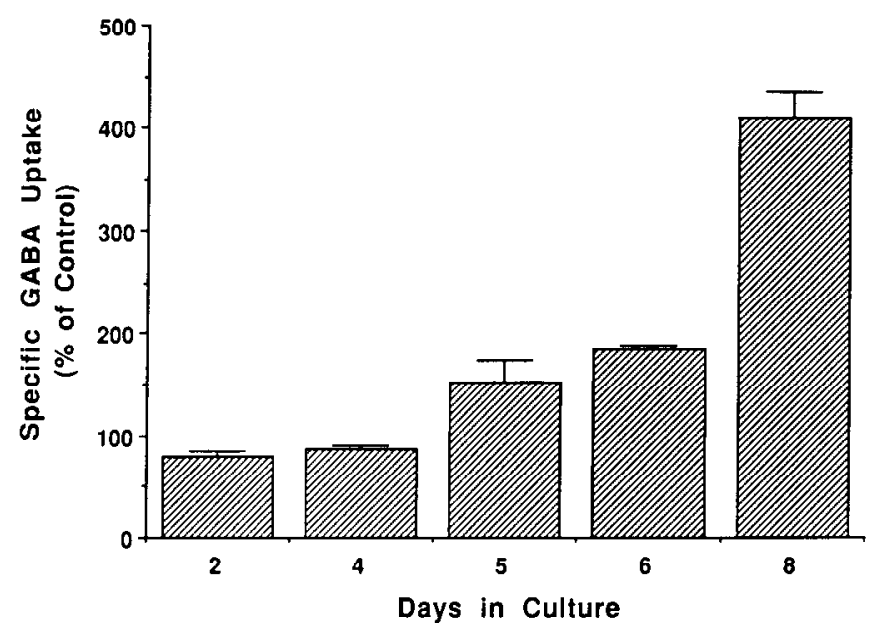

Figure 6. Time course of the level of high-affinity specific neuronal GABA uptake in CNTF-treated hippocampal cultures. Hippocampal neurons were cultured and maintained in the presence or absence of CNTF $(10 \mathrm{ng} / \mathrm{ml})$ for various periods (2-8 d) prior to measurement of GABA uptake. The results represent the level of GABA uptake of treated cultures expressed as a percentage of untreated control \pm SEM $(n=6-$ 12).

of cultures treated with these antimitotic agents showed depletion of non-neuronal cells. Based on immunoreactivity for GFAP, treatment of cultures with 0.3 or $1 \mu \mathrm{M} \mathrm{AraC} \mathrm{(or} 15 \mu \mathrm{g} / \mathrm{ml} \mathrm{FUdr)}$ resulted in a $57 \%$ and $77 \%$ reduction of the glial population, respectively. Under these conditions, the maximum response to CNTF in glial-depleted cultures was essentially the samc as in our standard cultures. As shown in Table 2, in cultures treated with $0.3 \mu \mathrm{M} \mathrm{AraC}, 1 \mathrm{ng} / \mathrm{ml}$ CNTF produced a maximum response of 2.6-fold increase in GABA uptake when compared to untreated controls. A CNTF-induced response of 3.2-fold was similarly observed in the presence of $1 \mu \mathrm{M}$ AraC. Thus, the foldstimulation in GABA uptake was similar in standard cultures $(-\mathrm{AraC})$ and in neuron-enriched cultures (+AraC). Similar results were obtained with FUdr. Although complete elimination of non-neuronal cells was not achieved, the above data tend to argue against a role of astrocytes mediating the action of CNTF and suggest that the effect is mediated via a direct action on neurons. In this context, it is noteworthy that recent studies have provided direct evidence for a neuronal binding site for CNTF on peripheral neurons (Squinto et al., 1990).

\section{Delaying the addition of CNTF results in a loss of responsive cells}

To distinguish between the possibilities of a survival-promoting effect and a phenotypic differentiation effect of CNTF on GABAergic neurons, CNTF was added at various times after plating, and the effect on the level of neuronal GABA uptake was measured. In the first set of experiments (Fig. 8A), CNTF was added after a delay of $5 \mathrm{hr}$ or $1,2,3$, or $4 \mathrm{~d}$, and the cultures were maintained for a total of $8 \mathrm{~d}$. Cultures that received CNTF $(10 \mathrm{ng} / \mathrm{ml})$ for the entire culture period showed a $420 \%$ increase in GABA uptake. A delay of $2 \mathrm{~d}(-2 /+6)$ in the addition of CNTF resulted in only a $240 \%$ increase in GABA uptake, while a delay of $3 \mathrm{~d}(-3 /+5)$ resulted in a total loss of the response. A further experiment was conducted to address the possibility that the lack of a response following a delay of $3 d(-3 /+5$; Fig. $8 A$ ) might have been due to not allowing sufficient time for the
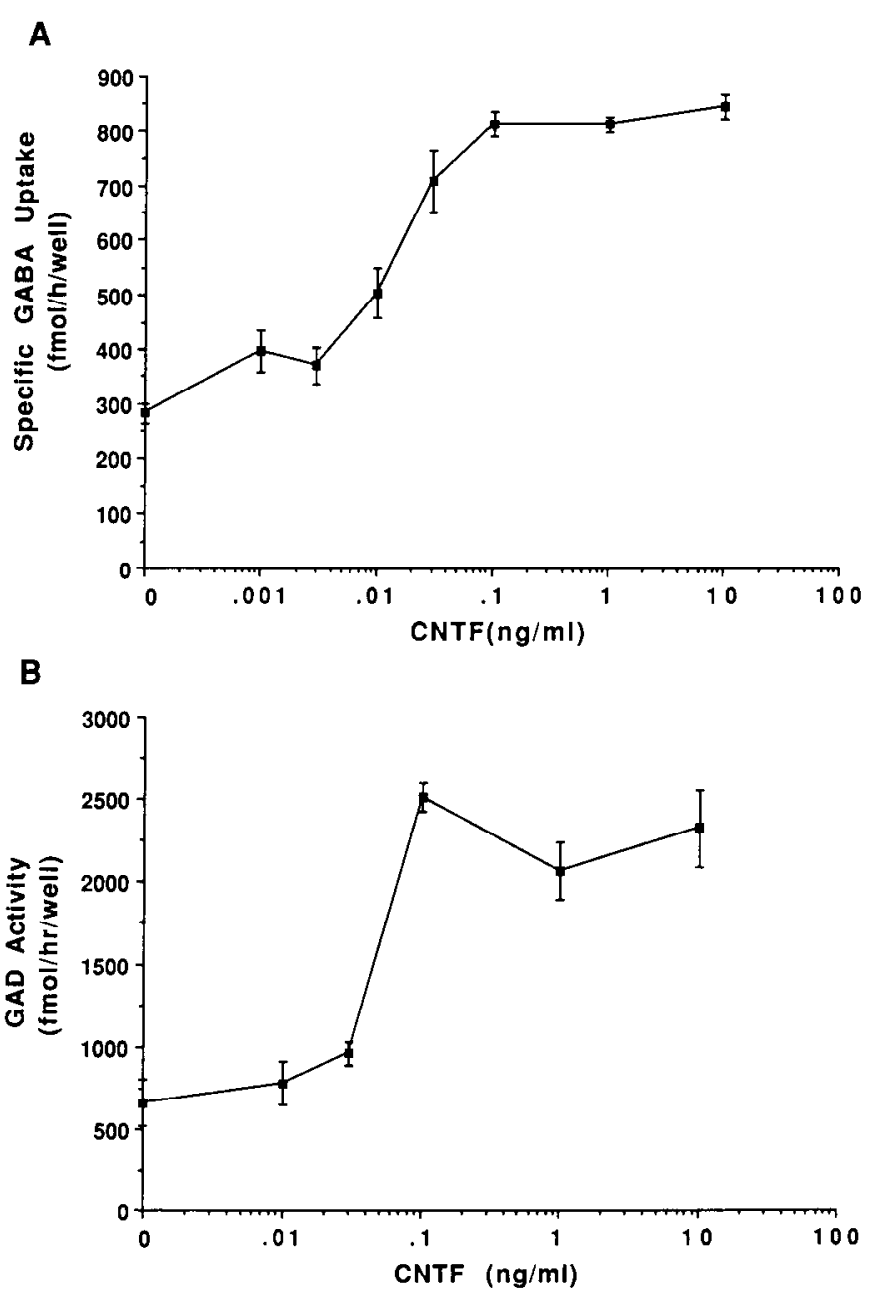

Figure 7. Dose-response curves of the CNTF-induced increase in GABA and GAD activity. Hippocampal neurons were cultured in the presence or absence of various concentrations of CNTF $(0.001-10 \mathrm{ng} /$ $\mathrm{ml}$ ) for $8 \mathrm{~d}$. At the end of the culture period, high-affinity specific neuronal GABA uptake $(A)$ and GAD enzyme activity $(B)$ were measured. The results represent the mean $\pm \operatorname{SEM}(n=5-12)$.

cells to respond maximally to CNTF. In this experiment, cultures that had not received CNTF for $3 \mathrm{~d}$ were grown in the presence of CNTF for a further $8 \mathrm{~d}$, thus extending the culture period to $11 \mathrm{~d}$. However, no increase in GABA uptake was observed even after this additional time in culture (Fig. $8 A$, inset). The qucstion as to whether or not all responsive neurons require CNTF for survival was addressed by similar delayed addition experiments where neurofilament protein content was measured. Results were essentially the same as seen for GABA uptake; that is, no increase in the neurofilament protein content compared to untreated controls was seen when the addition of CNTF was delayed for 3 or more days. Similar experiments were performed to examine the effects of delaying the addition of CNTF on the number of AChE-positive cells. Whereas treatment of cultures with CNTF for the entire period of $8 \mathrm{~d}$ produced a 28-fold increase in the number of AChE-positive cells, delaying the addition of CNTF for $3 \mathrm{~d}$ failed to elicit any increase in the number of cholinergic neurons (Fig. $8 B$ ). Therefore, on the basis of neurofilament protein, GABA uptake, and AChE histochemistry, a delay in the addition of CNTF appeared to result in a loss of responsive neuronal cell populations. 


\section{Discussion}

CNTF distinguishes itself from the recently identified neurotrophin family of neurotrophic factors (Leibrock et al., 1989; Maisonpierre et al., 1990a) in both molecular characteristics and biological specificities. Although the mechanism of release of CNTF from its site of synthesis is currently unknown, it is now well documented that $\mathrm{CNTF}$ has clearly defined actions toward several distinct neuronal populations in culture (Ernsberger et al., 1989; Saadat et al., 1989), including parasympathetic neurons of the chick ciliary ganglion (Barbin et al., 1984; Manthorpe and Varon, 1985) and motor neurons (Arakawa et al., 1990). In this article, we have provided evidence of a novel action of CNTF toward embryonic rat hippocampal neurons in culture. Treatment of hippocampal neurons with CNTF was first observed to result in a large increase in neurofilament protein levels when compared to untreated controls. Using neuronal subtype-specific markers, we have subsequently defined three subpopulations of hippocampal neurons whose survival were enhanced in the presence of CNTF. In the absence of neuronal markers whose expression is independent of trophic factor, it is of course difficult in control cultures to distinguish between death of a minor population of neurons or loss of the phenotypic marker that defines that population. This issue has been difficult to address with almost all in vitro studies with NGF. Whereas it is possible that some of the effects of CNTF were due to selective induction of specific phenotypic markers rather than enhancement of survival, the results of the delayed addition experiments argued against the former. Furthermore, the effects of CNTF were not diminished in cultures depleted of non-neuronal cells, suggesting that the actions of CNTF were not mediated via glial cells.

Hippocampal neurons in culture have been well characterized in terms of morphology, neurotransmitter content (Banker and Cowan, 1977, 1979; Mattson, 1988), and electrophysiological properties, as reviewed in Mayer and Westbrook (1987). Studies on the developmental profile of neuronal cell-type morphology have shown that neurons in culturc differentiatc in a manner that closely represents the in vivo situation (Banker and Cowan, 1979; Bartlett and Banker, 1984a,b). However, few studies have examined possible trophic effects of defined growth factors upon hippocampal neurons in culture. The observation that survival of hippocampal neurons in culture was enhanced in the presence of astrocytes (Banker, 1980; Müller and Seifert, 1982) was the first to suggest that glial cells might provide trophic support for these neurons. In light of what is now known, it is possible that the trophic activity derived from astrocytes may have been CNTF or basic FGF (bFGF) or a member of the neurotrophin family. In this context, it has been reported that bFGF promotes the survival of hippocampal neurons (Walicke, 1986). Beyond this, there is little information on the effects of known neurotrophic factors on hippocampal neurons.

In the present study, we have observed on average a 2.4 -fold increase in neuronal cell number in CNTF-treated hippocampal culture following $8 \mathrm{~d}$ in vitro. Interestingly, this increase in cell survival was accompanied hy a greater (fivefold) increase in neurofilament protein levels. This difference suggests that CNTF may promote neurite outgrowth in addition to its effect on cell survival. The time course of the increase in neurofilament protein in hippocampal cultures is of interest in that we did not observe a significant difference in neurofilament protein content between CNTF-treated and untreated controls until day 6 in
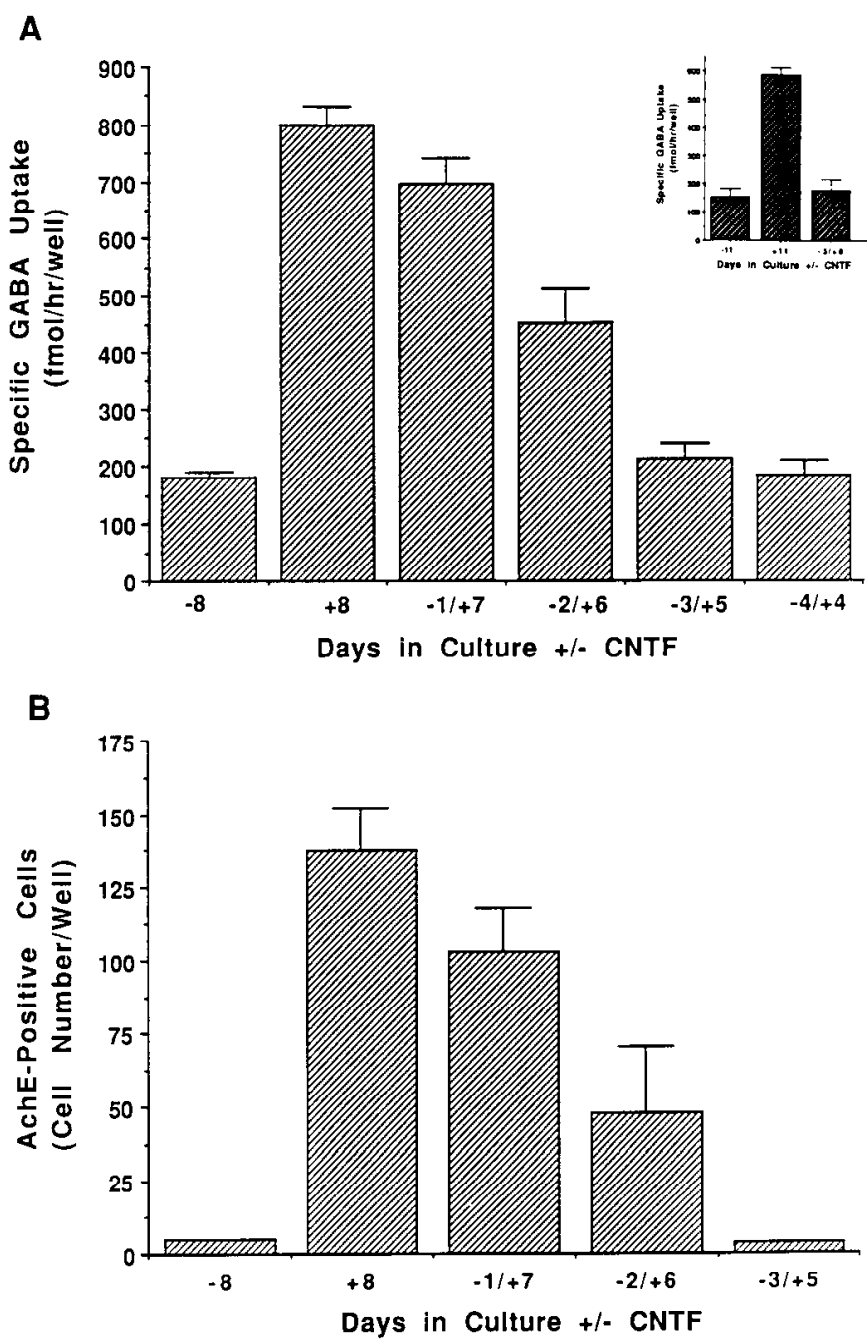

Figure 8. Effects of delaying the addition of CNTF on the CNTFinduced increase in high-affinity specific neuronal GABA uptake. $A$, CNTF $(10 \mathrm{ng} / \mathrm{ml})$ was added following a delay of 5-6 hr $(+8)$ or $1(-1 /$ $+7), 2(-2 /+6), 3(-3 /+5)$, or $4 \mathrm{~d}(-4 /+4)$ after cells were plated. High-affinity specific neuronal GABA uptake was determined on day 8 in culture. -8 indicates control cultures without $\mathrm{CNTF}$ treatment. Inset, CNTF $(10 \mathrm{ng} / \mathrm{ml})$ was added to the cultures following a delay of $5-6 \mathrm{hr}$ $(+11)$ or $3 \mathrm{~d}(-3 /+8)$, and high-affinity specific neuronal GABA uptake was determined on day 11 in culture. $-I l$ indicates control cultures without CNTF treatment. $B$, CNTF $(10 \mathrm{ng} / \mathrm{ml})$ was added following a delay of $5-6 \mathrm{hr}(+8)$ or $1(-1 /+7), 2(-2 /+6)$, or $3 \mathrm{~d}(-3 /+5)$ after the cells were plated. Histochemical staining for AChE-positive cells was performed on day 8 in culture $(n=10) .-8$ indicates control cultures without CNTF treatment. The results represent the mean \pm SEM.

culture. One potential influence on the early development of hippocampal neurons in vitro is the presence of endogenous trophic activity. For example, CNTF-like activity has been detected in the culture medium of glial cells $1 \mathrm{~d}$ after plating but was absent at later times (Rudge et al., 1985). Thus, it is possible that early in the culture period there was sufficient endogenous levels of trophic activity to enhance survival and initiate expression of neurofilament protein, such that the immediate actions of exogenous CNTF were not obvious.

GABAergic cells were one of the major cell types that were found to be responsive to CNTF. In agreement with previous studies (Walker and Peacock, 1982; Seifert et al., 1983; Hoch and Dingledine, 1986), the percentage of GABAergic cells in 
our cultures was approximately $20 \%$. We observed not only an increased number of GABAergic cells, as determined by immunocytochemistry, but also increases in GABA uptake and GAD enzyme activity in CNTF-treated cultures. Over the $8 \mathrm{~d}$ time course of our experiments, there was virtually no loss of GABAergic cells when CNTF was present. In accordance with the fact that GABA is an inhibitory transmitter, our finding that CNTF increases the number of GABAergic neurons in vitro may have important physiological implications in vivo.

The survival-promoting activity of CNTF on hippocampal neurons does not appear to be limited to GABAergic neurons. We have observed that the number of AChE-immunopositive cells was greatly increased in the presence of CNTF. The magnitude of the increase (28-fold) was much higher than that observed for GABAergic neurons. Furthermore, the intensity of the AChE histochemical staining was also much more pronounced in CNTF-treated cultures, suggesting that CNTF is capable of enhancing the phenotypic marker specific for such neurons. A similar increase in the number of cholinergic neurons was also observed using ChAT immunocytochemistry. Extremely low abundance of such cholinergic neurons precluded more detailed analysis by either ChAT or AChE enzyme assay. In marked contrast to the well-documented effect of NGF on cholinergic neurons in septal cultures (Hartikka and Hefti, 1988; Alderson et al., 1990), we found no such effect of NGF on the number of AChE-positive neurons in hippocampal cultures. Thus, these data, taken together, not only suggest a novel role for CNTF on a CNS cholinergic cell population but also indicate that this effect is not mediated by an indirect release of NGF from astrocytes present in the cultures. In light of a previous study in which CNTF was not found to enhance ChAT activity in cultures of septum or pons (Knusel and Hefti, 1988), our results suggest that CNTF acts on select populations of CNS cholinergic neurons.

A third cell type that was affected by CNTF was cells immunopositive for calbindin, one of a class of calcium-binding proteins $(\mathrm{CaBP})$ that bind $\mathrm{Ca}^{2+}$ with high affinity (Persechini et al., 1989). Immunohistochemical studies have shown a widespread distribution of the $28 \mathrm{kDa}$ species of calbindin in the CNS (Baimbridge and Miller, 1982; Baimbridge et al., 1982; Feldman and Christakos, 1983). In the hippocampus, calbindin has been localized to the somata of cells positioned in the molecular and granule cell layers of the dentate region and in the CAl region (Baimbridge and Miller, 1982). Relatively little is known concerning the regulation or the physiological function of calbindin in brain. However, in a recent study, decreases of up to $60-80 \%$ in the levels of both the message and protein for calbindin were observed in the hippocampus of patients who were diagnosed as having Parkinson's, Huntington's, or Alzheimer's disease (McLachlan et al., 1987; Iacopino and Christakos, 1990). In addition, it has recently been shown that the presence of calbindin in specific regions of the hippocampal formation may be positively correlated with the relative resistance of such neurons to seizure-induced neuronal damage (Sloviter, 1989). In the present study, we have shown that the number of calbindin-immunopositive cells was increased by threefold following CNTF treatment. Such an increase in $\mathrm{Ca}^{2+}$-binding capacity may have a significant physiological implication in that it may be important in preventing cell death in select populations of hippocampal neurons.

Although CNTF had survival effects on the three neuronal populations described above, the overall percentage of hippo- campal neurons supported by CNTF was relatively small (Fig. 5). This is indicative of the limited specificity of CNTF for the three populations described. However, the increment in NSEpositive cells at $8 \mathrm{~d}$, as a consequence of CNTF treatment, was larger than that accounted for by the observed increase in the number of GABAergic, cholinergic, and calbindin-immunopositive cells. This would argue that there is at least another population of hippocampal neurons that is responsive to CNTF. We are currently establishing reliable markers to investigate the effects of CNTF on other neuronal populations such as the glutamatergic neurons.

The specificity of the response of hippocampal neurons to CNTF was addressed by examining the actions of other neurotrophic factors, especially those of the neurotrophin family. The latter are of particular interest in that not only is NGF expressed at high levels in the hippocampus (Korsching et al., 1985; Shelton and Reichardt, 1986; Large et al., 1987), but also both BDNF and NT-3 mRNA levels are abundant in the hippocampal formation (Maisonpierre et al., 1990b). We were not able to detect any effect of NGF on GABAergic neurons or cholinergic neurons in hippocampal cultures. These data suggest that the effect of CNTF was not mediated via the release of NGF from hippocampal cells. However, we cannot rule out the possibility that the actions of CNTF might have been mediated indirectly through BDNF or NT-3 or an as yet unidentified factor.

mRNA for CNTF has recently been detected in the CNS, including the hippocampal formation, by Northern blot analysis (Ip, Masiakowski, and Yaneopoulos, unpublished observations). The cell-type specificity of CNTF synthesis in hippocampus in vivo, however, has not yet been delineated. Similar to bFGF, sequence analysis of CNTF shows that it lacks a typical signal sequence, and it is thus not yet clear how CNTF could be made available to neurons. There is now considerable evidence that at least two members of the neurotrophin family (NGF and BDNF), which are expressed at high levels in the hippocampus, may act as target-derived factors for neuronal populations that project to the hippocampus (Hartikka and Hefti, 1988; Alderson et al., 1990). CNTF, on the other hand, may bc different, acting in a local manner on hippocampal neurons.

The hippocampal formation has been shown to be affected in several neurodegenerative disorders, including Alzheimer's disease (Hyman and Hoesen, 1989). The underlying mechanisms that lead to the selective neuronal degeneration within the hippocampus are not well understood. It has been hypothesized that the excitatory amino acid neurotransmitter glutamate may be involved in the disease process (Schwarcz et al., 1984; Maragos et al., 1987; Choi, 1988). Thus, it will be interesting to investigate whether CNTF is able to protect hippocampal neurons against the well-documented neurotoxicity of glutamate (Foster et al., 1988; Mattson et al., 1988). Although the physiological role of CNTF in the hippocampus during development in vivo remains to be established, in view of the present findings, CNTF may be an endogenous neurotrophic factor with a potential role in regulating neuronal survival in the hippocampus.

\section{References}

Adler R, Landa KB, Manthorpe M, Varon S (1979) Cholinergic neuronotrophic factors: intraocular distribution of soluble trophic activity for ciliary neurons. Science 204:1434-1436.

Alderson RF, Alterman AL, Barde Y-A, Lindsay RM (1990) Brain- 
derived neurotrophic factor increases survival and differentiated functions of rat septal cholinergic neurons in culture. Neuron 5:297-306. Arakawa Y, Sendtner M, Thoenen H (1990) Survival effect of ciliary neurotrophic factor (CNTF) on chick embryonic motoneurons in culture: comparison with other neurotrophic factors and cytokines. J Neurosci 10:3507-3515.

Baimbridge KG, Miller JJ (1982) Immunohistochemical localization of calcium-binding protein in the cerebellum, hippocampal formation and olfactory bulb of the rat. Brain Res 245:223-229.

Baimbridge KG, Miller JJ, Parkes CO (1982) Calcium-binding protein distribution in the rat brain. Brain Res 239:519-525.

Banker GA (1980) Trophic interactions between astroglial cells and hippocampal neurons in cultures. Science 209:809-810.

Banker GA, Cowan WM (1977) Rat hippocampal neurons in dispersed cell culture. Brain Res 126:397-425.

Banker GA, Cowan WM (1979) Further observations on hippocampal neurons in dispersed cell culture. J Comp Neurol 187:469-494.

Barhin G, Manthorpe M, Varon S (1984) Purification of the chick eye ciliary neuronotrophic factor. J Neurochem 43:1468-1478.

Barde Y-A (1988) What, if anything, is a neurotrophic factor? Trends Neurosci 11:343-346.

Barde Y-A (1989) Trophic factors and neuronal survival. Neuron 2: $1525-1534$.

Barde Y-A, Edgar D, Thoenen H (1982) Purification of a new neurotrophic factor from mammalian brain. EMBO J 1:549-553.

Bartlett WP, Banker GA (1984a) An electron microscopic study of the development of axons and dendrites by hippocampal neurons in culture. I. Cells which develop without intercellular contacts. J Neurosci 4:1944-1953.

Bartlett WP, Banker GA (1984b) An electron microscopic study of the development of axons and dendrites by hippocampal neurons in culture. II. Synaptic relationships. J Neurosci 4:1954-1965.

Blottner D, Brüggemann W, Unsicker K (1989) Ciliary neurotrophic factor supports target-derived preganglionic sympathetic spinal cord neurons. Neurosci Lett 105:316-320.

Choi DW (1988) Glutamate neurotoxicity and diseases of the nervous system. Neuron 1:623-634.

Doherty P, Dickson JG, Flanigan TP, Walsh FS (1984) Quantitative evaluation of neurite outgrowth in cultures of human foetal brain and dorsal root ganglion cells using an enzyme-linked immunoabsorbent assay for human neurofilament protein. J Neurochem 42:1116-1122.

Doherty P, Mann DA, Walsh FS (1987) Cholera toxin and dibutyryl cyclic AMP inhibit the expression of neurofilament protein induced by nerve growth factor in cultures of naive and primed PC12 cells. J Neurochem 49:1676-1687.

Frnsberger V, Sendtner M, Rohrer H (1989) Proliferation and differentiation of embryonic chick sympathetic neurons: effects of ciliary neurotrophic factor. Neuron 2:1275-1284.

Feldman SC, Christakos S (1983) Vitamin D-dependent calciumbinding protein in rat brain: biochemical and immunocytochemical characterization. Endocrinology 112:290-302.

Fonnum F, Lund-Karlsen R, Malthe-Sørenssen D, Skrede K, Walaas I (1979) Localization of neurotransmitters, particularly glutamate, in hippocampus, septum, nucleus accumbens and superior colliculus. Adv Brain Res 51:167-191.

Foster AC, Gill R, Woodruff GN (1988) Neuroprotective effects of MK-801 in vivo: selectivity and evidence for delayed degeneration mediated by NMDA receptor activation. J Neurosci 8:4745-4754.

Frotscher M, Schlander M, Leranth C (1986) Cholinergic neurons in the hippocampus: a combincd light and clectron microscopic immunocytochemical study in the rat. Cell Tissue Res 246:293-301.

Geneser-Jensen FA, Blackstadt TE (1971) Distribution of acetylcholinesterase in the hippocampal region of the guinea pig. 1. Entorhinal area parasubiculum, and pre-subiculum. Z Zellforsch 114:460-481.

Hartikka J, Hefti F (1988) Development of septal cholinergic neurons in culture: plating density and glial cells modulate effects of NGF on survival, fiber growth and expression of transmitter-specific enzymes. J Neurosci 8:2967-2985.

Hoch DB, Dingledine R (1986) GABAergic neurons in rat hippocampal culture. Dev Brain Res 25:53-64.

Hohn A, Leibrock J, Bailey K, Barde Y-A (1990) Identification and characterization of a novel member of the nerve growth factor/brainderived neurotrophic factor family. Nature 344:339-341.

Hyman BT, van Hoesen GW (1989) Hippocampal and entorhinal cortex cellular pathology in Alzheimer's disease. In: The hippocam- pus-new vistas (Chan-Palay V, Kohler C, eds), pp 499-512. New York: Liss.

Iacopino AM, Christakos S (1990) Specific reduction of calcium-binding protein (28-kilodalton calbindin-D) gene expression in aging and neurodegenerative diseases. Proc Natl Acad Sci 87:4078-4082.

Kimura H, Kuriyama K (1975) A new microassay method for L-glutaminic acid decarboxylase (GAD) activity. Jpn J Pharmacol 25: 189-195.

Knusel B, Hefti F (1988) Development of cholinergic pedunculopontine neurons in vitro: comparison with cholinergic septal cells and response to nerve growth factor, ciliary neuronotrophic factor, and retinoic acid. J Neurosci Res 21:365-375.

Korsching S, Auburger G, Heumann R, Scott J, Thoenen H (1985) Levels of nerve growth factor and its mRNA in the central nervous system of the rat correlate with cholinergic innervation. EMBO J 4: $1389-1393$.

Large TH, Bodary SC, Clegg DO, Weskamp G, Otten U, Reichardt LF (1987) Nerve growth factor gene expression in the developing rat brain. Science 234:352-355.

Leibrock J, Lottspeich F, Hohn A, Hengerer B, Masiakowski P, Thoenen H, Barde Y-A (1989) Molccular cloning and expression of brain derived neurotrophic factor. Nature 341:149-152.

Levi-Montalcini R, Angeletti PU (1968) Nerve growth factor. Physiol Rev 48:534-569.

Lin L-FH, Mismer D, Lile JD, Armes LG, Butler ET III, Vannice JL, Collins F (1989) Purification, cloning and expression of ciliary neurotrophic factor (CNTF). Science 246:1023-1025.

Lin L-FH, Armes LG, Sommer A, Smith DJ, Collins F (1990) Isolation and characterization of ciliary neurotrophic factor from rabbit sciatic nerves. J Biol Chem 265:8942-8947.

Lindsay RM (1988) The role of neurotrophic growth factors in development, maintenance and regeneration of sensory neurons. In: The making of the nervous system (Parnavelas JG, Stern CD, Stirling RV, eds), pp 149-165. Oxford: Oxford UP.

Maisonpicrrc PC, Bclluscio L, Squinto SP, Ip NY, Furth ME, Lindsay RM, Yancopoulos GD (1990a) Neurotrophin-3: a neurotrophic factor related to NGF and BDNF. Science 247:1446-1451.

Maisonpierre PC, Belluscio L, Friedman B, Alderson R, Weigand S, Furth ME, Lindsay, RM, Yancopoulos GD (1990b) NT-3, BDNF and NGF in the developing rat nervous system: parallel as well as reciprocal patterns of expression. Neuron 5:501-509.

Manthorpe M, Varon S (1985) Regulation of neuronal survival and neurite growth in the avian ciliary ganglion by trophic factors. In Growth and maturation factors, Vol. 3 (Guroff G, ed), pp 77-117. New York: Wiley.

Manthorpe M, Skaper SD, Williams LR, Varon S (1986a) Purification of adult rat sciatic nerve ciliary neurotrophic factor. Brain Res 367 : 282-286.

Manthorpe M, Rudge JS, Varon S (1986b) Astroglial contribution to neuronal survival and neuritic growth. In: Astrocytes, biochemistry, physiology, and pharmacology of astrocytes, Vol 2 (Fedoroff S, Vernadakis A, eds), pp 315-376. New York: Academic.

Maragos WF, Greenamyre JT, Penney JB Jr, Young AB (1987) Glutamate dysfunction in Alzheimer's disease: an hypothesis. Trends Neurosci 10:65-68.

Masiakowski P, Liu H, Radziejewski C, Lottspeich F, Oberthuer W, Wong V, Lindsay RM, Furth ME, Panayotatos N (1991) Recombinant human and rat ciliary neurotrophic factors. J Neurochem, in press.

Mattson MP (1988) Neurotransmitters in the regulation of neuronal cytoarchitecture. Brain Res Rev 13:179-212.

Mattson MP, Duo P, Kater SB (1988) Outgrowth-regulating actions of glutamate in isolated hippocampal pyramidal neurons. J Neurosci 8:2087-2100.

Mayer ML, Westbrook GL (1987) The physiology of excitatory amino acids in the vertebrate central nervous system. Prog Neurobiol 28 : 197-276.

McLachlan DR, Wong L, Bergeron C, Baimbridge KG (1987) Calmodulin and calbindin $\mathrm{D}_{28 \mathrm{~K}}$ in Alzheimer disease. Alzheimer Dis Assoc Disord 1:171-179.

Müller HW, Seifert W (1982) A neurotrophic factor (NTF) released from primary glial cultures supports survival and fiber outgrowth of cultured hippocampal neurons. J Neurosci Res 8:195-204.

Persechini A, Moncrief ND, Kretsinger RH (1989) The EF-hand family of calcium-modulated proteins. Trends Neurosci 12:462-467. 
Purves D (1988) A molecular basis for trophic interactions in vertebrates. In: Body and brain, a trophic theory of neural connections, pp 123-141. Cambridge: Harvard UP.

Robinson PA, Anderton BH (1988) Neurofilament probes-a review of neurofilament distribution and biology. Rev Neurosci 2:1-40.

Romijn HJ, Haberts AMMC, Mud MJ, Wolters PS (1982) Nerve outgrowth, synaptogenesis, and bioelectric activity in fetal rat cerebral cortex tissue cultured in serum-free, chemically defined medium. Dev Brain Res 2:583-589.

Rudge JS, Manthorpe M, Varon S (1985) The output of neuronotrophic and neurite-promoting agents from rat brain astroglial cells: a microculture method for screening potential regulatory molecules. Dev Brain Res 19:161-172.

Saadat S, Sendtner M, Rohrer H (1989) Ciliary neurotrophic factor induces cholinergic differentiation of rat sympathetic neurons in culture. J Cell Biol 108:1807-1816.

Schwarcz R, Foster AC, French ED, Whetsell WO Jr, Kohler C (1984) Excitotoxic models for neurodegenerative disorders. Life Sci 35:1932.

Seifert W, Ranscht B, Fink HJ, Forster F, Beckh S, Müller HW (1983) Development of hippocampal neurons in cell culture: a molecular approach. In: Neurobiology of the hippocampus (Seifert W, ed), pp 109-135. New York: Academic.

Sendtner M, Kreutzberg GW, Thoenen H (1990) Ciliary neurotrophic factor prevents the degeneration of motor neurons after axotomy. Nature 345:440-441.

Shelton DL, Reichardt LF (1986) Studies on the expression of the B nerve growth factor (NGF) gene in the central nervous system: level and regional distribution of NGF and mRNA suggest that NGF functions as a trophic factor for several distinct populations of neurons. Proc Natl Acad Sci USA 83:2714-2718.

Sloviter RS (1989) Calcium-binding protein (calbindin-D28k) and parvalbumin immunocytochemistry: localization in the rat hippocampus with specific reference to the selective vulnerability of hippocampal neurons to seizure activity. J Comp Neurol 280:183-196.

Squinto SP, Aldrich TH, Lindsay RM, Morrissey DM, Panayotatos N, Bianco SM, Furth ME, Yancopoulos GD (1990) Identification of functional receptors for ciliary neurotrophic factor on neuronal cell lines and primary neurons. Neuron 5:757-766.

Stöckli KA, Lottspeich F, Sendtner M, Masiakowski P, Carroll P, Götz R, Lindholm D, Thoenen H (1989) Molecular cloning, expression and regional distribution of rat ciliary neurotrophic factor. Nature 342:920-923.

Storm-Mathisen J (1970) Quantitative histochemistry of acetylcholinesterase in rat hippocampal region correlated to histochemical staining. J Neurochem 17:739-750.

Thoenen H, Barde Y-A (1980) Physiology of nerve growth factor. Physiol Rev 60:1284-1335.

Thoenen H, Bandtlow C, Heumann R (1987) The physiological function of nerve growth factor in the central nervous system: comparison with the periphery. Rev Physiol Biochem Pharmacol 109:146-178.

Tomozawa Y, Appel SH (1986) Soluble striatial extracts enhance development of mesencephalic dopaminergic neurons in vitro. Brain Res 399:111-124.

Walicke P, Cowan WM, Ueno N, Baird A, Guillemin R (1986) Fibroblast growth factor promotes survival of dissociated hippocampal neurons and enhances neurite extension. Proc Natl Acad Sci USA $83: 3012-3016$.

Walker CR, Peacock JH (1982) Development of GABAergic function of dissociated hippocampal cultures from fetal mice. Dev Brain Res 2:541-555.

Wong V, Arriaga R, Lindsay RM (1990) Effects of ciliary neurotrophic factor (CNTF) on ventral spinal cord neurons in culture. Soc Neurosci Abstr 16:484. 